\title{
SKRENING BAKTERI TOLERAN PESTISIDA DENGAN BAHAN AKTIF KLORANTRANILIPROL ASAL TANAH PERTANIAN BATURITI TABANAN BALI
}

\author{
SCREENING OF CHLORANTRANILIPROLE TOLERANT BACTERIA \\ FROM BATURITI CULTIVATED SOIL, TABANAN-BALI
}

\author{
NI KADEK WIWIK SINTA DEWI*, IDA BAGUS GEDE DARMAYASA, I KETUT SUNDRA \\ Prodi Biologi FMIPA Universitas Udayana Bukit Jimbaran-Bali \\ *Email: wiwiksinta@gmail.com
}

Naskah diterima 4 Oktober 2016, Naskah disetujui 20 Desember 2016

\section{INTISARI}

Pertanian di Indonesia umumnya masih banyak menggunakan pestisida kimia baik berupa insektisida, herbisida, dan fungisida, yang memiliki toksisitas tinggi dan persistensi lama dalam tanah sehingga berpotensi mencemari lingkungan. Salah satu jenis insektisida yang digunakan pada salah satu pertanian di Baturiti Tabanan adalah Prevathon yang memiliki bahan aktif Klorantraniliprol. Di dalam tanah terdapat bakteri-bakteri yang berperan dalam mendegradasi senyawa-senyawa kimia berbahaya menjadi senyawa yang lebih sederhana, sehingga bakteri tersebut dimanfaatkan sebagai agen bioremediasi tanah. Tujuan penelitian ini adalah untuk skrening bakteri toleran pestisida dengan bahan aktif Klorantraniliprol dengan menggunakan media mineral dan diperkaya pestisida Prevathon serta mengidentifikasi hingga tingkat genus atau spesies. Penelitian dilakukan di Laboratorium Mikrobiologi Fakultas Matematika dan Ilmu Pengetahuan Alam Universitas Udayana, dengan 3 analisis, yaitu (1) uji bakteri toleran pestisida pada media mineral dengan pestisida Prevathon, (2) karakterisasi bakteri, (3) Identifikasi bakteri toleran pestisida dengan BD BBL Crystal Enteric/Non Fermenter ID Kit. Hasil menunjukkan bahwa perlakuan media mineral dengan penambahan pestisida Prevathon $(0,5,10,15 \mathrm{ppm})$ mampu memberikan pengaruh yang berbeda nyata pada pengkayaan 1, 2 dan $3(\mathrm{P}<0,05)$, serta terdapat 5 isolat bakteri yang diisolasi dari tanah pertanian Baturiti Tabanan yaitu BSP 1, BSP 2, BSP 3 yang merupakan bakteri Gram negatif, BSP 4 dan BSP 5 adalah bakteri Gram positif. Bakteri yang toleran terhadap pestisida dengan bahan aktif Klorantraniliprol adalah BSP 2 dan teridentifikasi sebagai bakteri Serratia marcescens.

\section{Kata kunci: Media mineral, Bakteri toleran pestisida, Prevathon, Serratia marcescens}

\begin{abstract}
In Indonesia agriculture practice often used the large scale pesticide application such as insecticide, herbicide, and fungicide. The wide use of toxic pesticide has created numerous problem in increasing environtmental hazard to human and to other animals. Many of soil bacteria had important role to degrading chemical compounds into simpler compounds as a bioremediation agent. The aim of this study was to screen the Chlorantraniliprole tolerant bacteria using soil mineral medium with Prevathon pesticide addition, also teo identificate the species of bacteria. This research was conducted at Microbiology Laboratory, Faculty of Mathematics and Natural Sciences, Udayana University. The research was done in three analysis, (1) bacteria test on Prevathon pesticide addition to mineral medium treatment, (2) characterization of bacteria, (3) Identification of pesticide tolerant bacteria with BD BBL Crystal Enteric/Non FermenterID Kit. The results showed that mineral medium with the addition of pesticides Prevathon treatment able to provide a significant different effect on the enrichment stage 1, stage 2 and stage $3(\mathrm{P}<0.05)$, there was 5 isolates pesticide tolerant bacteria that isolated from Baturiti Tabanan cultivated soil that was BSP 1, BSP 2, BSP 3 known as gram negative bacteria, and BSP 4, BSP 5 known as Gram positive bacteria, pesticide tolerant bacteria identified as Serratia marcescens which is a Gram negative bacteria group and may cause pathogenic.
\end{abstract}

Key words: Soil Mineral medium, Prevathon, Serratia marcescens 


\section{PENDAHULUAN}

Indonesia merupakan salah satu negara agraris yang mengandalkan sektor pertanian dalam pemenuhan kebutuhan pangan masyarakat. Bali adalah salah satu provinsi di Indonesia yang masyarakatnya masih dominan bermata pencaharian sebagai petani. Salah satu kabupaten di Bali yang terkenal dengan produk hasil pertaniannya adalah kabupaten Tabanan. Desa Baturiti adalah salah satu desa di wilayah Kabupaten Tabanan Bali dan merupakan daerah pegunungan dengan ketinggian 700-925 meter dari permukaan laut. Kesuburan tanah Desa Baturiti adalah bagian dari ekosistem tanah pegunungan dengan kondisi tanahnya berpasir dengan jenis regosol coklat kelabu dan merupakan bagian dari tanah pegunungan berbentuk (topografi) lereng dan ngarai (Soeriadireja dkk., 2014). Baturiti memiliki udara yang sejuk dengan suhu maksimum di kawasan Candikuning/Bedugul sebesar $22,4^{\circ} \mathrm{C}$ dengan suhu minimum sebesar $15,4^{\circ} \mathrm{C}$ dengan suhu ratarata sebesar $19,5^{\circ} \mathrm{C}$, serta memiliki tanah yang subur untuk ditanami sayur-sayuran seperti kubis, sawi, dan tanaman bunga. Tanaman kubis (Brassica oleracea L.) merupakan komoditi utama sayur-sayuran di Desa Baturiti.

Tanaman kubis adalah salah satu komoditi hortikultura yang cukup penting bagi masyarakat. Produksi kubis di Indonesia tergolong tinggi yaitu pada tahun 2010 adalah sebesar 20,51 ton/hektar, dan tahun 2011 sebesar 21,14 ton/hektar (Patty, 2012). Upaya untuk meningkatkan produksi kubis sampai saat ini masih mengalami kendala akibat serangan hama atau Organisme Pengganggu Tanaman (OPT). Pengendalian hama perlu dilakukan petani untuk menekan resiko penurunan hasil produksi yang disebabkan oleh OPT dengan mengaplikasikan pestisida pada lahan pertanian atau dengan melakukan pemupukan. Kebanyakan petani lebih mengandalkan pengendalian secara kimiawi dengan menggunakan pestisida sebagai pengendali hama. Salah satu insektisida yang baru dikembangkan adalah insektisida golongan Diamida dengan bahan aktif Klorantraniliprol dipasarkan oleh DuPont. Menurut hasil penelitian Maruli dkk. (2012), insektisida dengan bahan aktif Klorantraniliprol masih meninggalkan residu insektisida pada tanaman kubis setelah pemanenan kubis sebesar $0,698 \mathrm{mg} / \mathrm{kg}$ dan direndam dengan menggunakan air PAM sebesar $0,526 \mathrm{mg} / \mathrm{kg}$. Insektisida sintetik dengan bahan aktif Klorantraniliprol merupakan formulasi yang baru namun sudah terdaftar di petanian seluruh dunia. Walaupun produknya sudah tersebar luas namun tidak banyak studi yang mengkaji tentang resiko penggunaan insektisida dengan bahan aktif Klorantraniliprol.

Beberapa mikroorganisme di dalam tanah mampu mengubah senyawa-senyawa kimia beracun pada lingkungan yang terkontaminasi menjadi produk yang tidak beracun. Peran mikroorganisme dalam mendegradasi senyawa pestisida sangat penting sebagai upaya bioremediasi, sehingga perlu dilakukan eksplorasi spesies mikroba yang dapat survive pada tanah yang tercemar pestisida dan memiliki potensi dalam mendegradasi insektisida Prevathon. Berdasarkan uraian tersebut maka dilaksanakan penelitian mengenai bakteri tanah yang mampu toleran pada media diperkaya pestisida Prevathon yang banyak digunakan oleh para petani di daerah Baturiti Tabanan Bali, melalui skrening bakteri toleran pestisida dengan bahan aktif Klorantraniliprol dengan menggunakan media mineral dan diperkaya pestisida Prevathon serta mengidentifikasi hingga tingkat genus atau spesies

\section{MATERI DAN METODE}

Sampel tanah diambil dari ladang pertanian sayur di Desa Baturiti Tabanan yang memiliki riwayat penggunaan pestisida dengan bahan aktif Klorantraniliprol. Isolasi bakteri pendegradasi dilakukan dengan menimbang $10 \mathrm{~g}$ tanah sumber mikroba potensial pendegradasi dan diencerkan dengan akuades steril sebanyak $90 \mathrm{~mL}$ kemudian divortex, dan dilakukan pengenceran sampai $10^{-3}$.Pengenceran $10^{-3}$ sebanyak $200 \mu \mathrm{L}$ dimasukkan ke dalam 4,8 mL ke masing-masing media cair yang mengandung10 g NaNO${ }_{3}, 2,5 \mathrm{~g} \mathrm{NH}_{4} \mathrm{Cl}, 2,6 \mathrm{~g} \mathrm{KH}_{2} \mathrm{PO}_{4}, 7,4$ $\mathrm{g} \mathrm{K}_{2} \mathrm{HPO}_{4}, 1 \mathrm{~g} \mathrm{MgSO}_{4}, 2 \mathrm{~g} \mathrm{CaCl}_{2}, \mathrm{O}, 01 \mathrm{~g} \mathrm{CuSO}_{4}, 0,025 \mathrm{~g}$ asam sitrat, 0,025 $\mathrm{g} \mathrm{FeSO}_{4}$, 0,1 g EDTA, $10 \mathrm{~mL}$ larutan multi element, dan $1 \mathrm{~g}$ glukosa (Wahyuni dkk., 2013). Dibuat dua media dengan ditambahkan glukosa dan tanpa penambahan glukosa. Selanjutnya dilakukan uji bakteri toleran pestisida pada media mineral dengan pestisida Prevathon. Disiapkan tabung reaksi steril, dipipet media mineral, kemudian masing-masing tabung reaksi diberi perlakuan sebagai berikut:

Tabung 1. Media mineral + glukosa (1000:1; \% v/v) tanpa pestisida

Tabung 2. Media mineral + glukosa dengan 5 ppm pestisida

Tabung 3. Media mineral + glukosa dengan $10 \mathrm{ppm}$ pestisida

Tabung 4. Media mineral + glukosa dengan 15 ppm pestisida

Tabung 5. Media mineral tanpa pestisida

Tabung 6. Media mineral dengan $5 \mathrm{ppm}$ pestisida

Tabung 7. Media mineral dengan $10 \mathrm{ppm}$ pestisida

Tabung 8. Media mineral dengan $15 \mathrm{ppm}$ pestisida

Konsentrasi insektisida campuran dibuat sebagai berikut: o, 5, 10, 15 ppm insektisida Klorantraniliprol kemudian diinkubasi di bioshaker dengan suhu ruang $\left( \pm 28^{\circ} \mathrm{C}\right)$ selama 5 hari. Pertumbuhan mikroba diamati dengan menggunakan metode turbidimetri yang diukur pada panjang gelombang $600 \mathrm{~nm}$. Reaksi positif ditunjukkan dengan perubahan kekeruhan pada media. Percobaan pengkayaan dilakukan dengan 3 kali ulangan.

Hasil positif dari tabung reaksi dipipet $1 \mathrm{~mL}$ dan dituangkan pada cawan Petri steril kemudian dituangkan media NA, diinkubasi selama 24-72 jam dengan suhu $37^{\circ} \mathrm{C}$. Kemudian dilakukan pemurnian isolat bakteri dengan diinokulasi koloni bakteri yang tumbuh pada media NA menggunakan jarum Ose dan digoreskan pada 
media NA miring, diinkubasi selama 24 jam pada suhu $30^{\circ} \mathrm{C}$. Selanjutnya dilakukan Karakterisasi bakteri dengan mengamati karakter makroskopis dan mikroskopis, serta dilakukan identifikasi dengan menggunakan BD BBL Crystal E/NF ID Kit.

Isolat yang berpotensi diuji kembali dengan dipipet sebanyak $200 \mu \mathrm{L}$ isolat murni pada media NB yang berumur 24 jam ke pada masing-masing media perlakuan. Isolat diujikan pada 3 perlakuan yaitu $15 \mathrm{ppm}$ pestisida Prevathon, Media mineral, dan media mineral dengan $15 \mathrm{ppm}$ pestisida. Masing-masing perlakuan dibuat sebanyak 4,8 mL dibuat ulangan sebanyak 3 kali, kemudian diinkubasi di bioshaker dengan suhu ruang $\left( \pm 28^{\circ} \mathrm{C}\right)$ selama 5 hari. Dibuat kontrol negatif untuk masing-masing perlakuan. Selain itu isolat ditumbuhkan pada media NA yang diperkaya dengan $15 \mathrm{ppm}$ pestisida, kemudian dilihat apakah isolat mampu tumbuh pada media yang diperkaya dengan pestisida.

Normalitas data diuji dengan program SPSS versi 15.0, dan apabila menunjukkan data yang normal, data kuantitatif dianalisis sidik ragam dengan menggunakan Analysis of varians (ANOVA). Jika terdapat perbedaan yang nyata pada pengaruh perlakuan dilanjutkan dengan uji jarak berganda dari Duncan $\mathrm{P}<0,05$.

\section{HASIL}

Pola pertumbuhan bakteri seperti yang disajikan pada Gambar 1 menunjukkan bahwa hari pertama sampai hari kelima inkubasi secara umum terjadi peningkatan jumlah populasi bakteri.

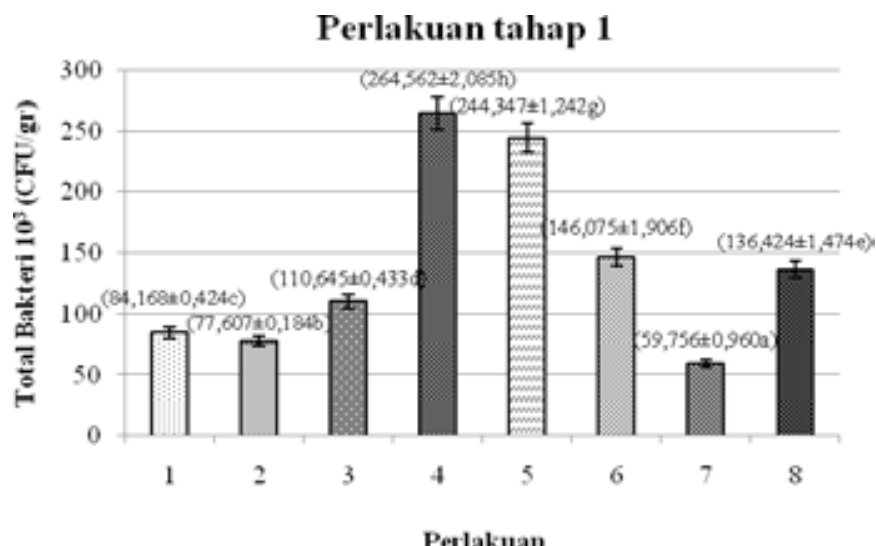

Gambar 1. Grafik jumlah total bakteri pada pengkayaan 1 masa inkubasi 5 hari

Keterangan :

a. (1) Media mineral + glukosa tanpa pestisida; (2) Media mineral + glukosa $5 \mathrm{ppm}$ pestisida; (3) Media mineral + glukosa $10 \mathrm{ppm}$ pestisida; (4) Media mineral + glukosa $15 \mathrm{ppm}$ pestisida; (5) Media mineral tanpa pestisida; (6) Media mineral $5 \mathrm{ppm}$ pestisida; (7) Media mineral $10 \mathrm{ppm}$ pestisida; (8) Media mineral 15 ppm pestisida

b. Notasi huruf yang sama menunjukkan nilai yang tidak berbeda nyata $(\mathrm{P}<0,05)$.

c. Angka dibelakang tanda $( \pm)$ menunjukkan standar deviasi.
Peningkatan secara signifikan terjadi pada perlakuan keempat yaitu pada perlakuan media mineral dengan glukosa dan dengan penambahan $15 \mathrm{ppm}$ pestisida yaitu $265 \times 10^{3} \mathrm{CFU} / \mathrm{gr}$, selanjutnya pada perlakuan kelima yang ditumbuhkan pada media mineral tanpa glukosa dan tanpa penambahan pestisida dengan jumlah populasi bakteri mencapai $244 \times 10^{3} \mathrm{CFU} / g r$. Rata-rata jumlah total bakteri pada perlakuan media mineral tanpa glukosa dengan penambahan $10 \mathrm{ppm}$ pestisida sebesar $60 \times 10^{3}$ $\mathrm{CFU} / \mathrm{gr}$, jauh lebih rendah dari perlakuan lainnya dan menunjukkan hasil yang berbeda nyata $(\mathrm{P}<0,05)$.

Konsistensi pertumbuhan mikroba tetap terjadi pada pengkayaan kedua seperti yang disajikan pada Gambar 2. Hampir disemua perlakuan selama masa inkubasi 5 hari berikutnya populasi mikroba tanah masih berada diatas $50 \times 10^{3} \mathrm{CFU} / \mathrm{gr}$, walaupun pada masing-masing perlakuan terjadi variasi jumlah total mikroba.

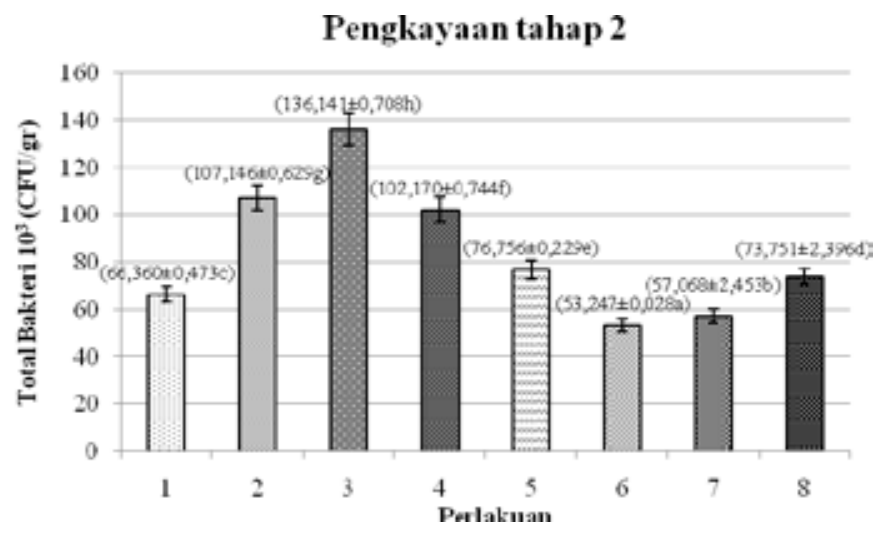

Gambar 2. Grafik jumlah total bakteri pada pengkayaan 2

Perlakuan media mineral dengan glukosa dan penambahan 10 ppm pestisida pada pengkayaan kedua terjadi peningkatan jumlah populasi bakteri sebesar $136 \times 10^{3}$ $\mathrm{CFU} / \mathrm{gr}$.

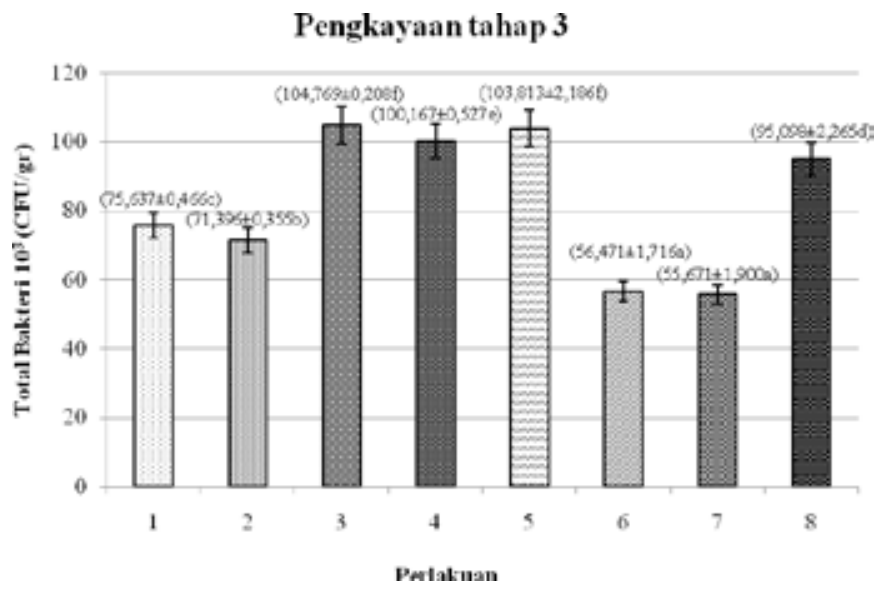

Gambar 3. Grafik jumlah total bakteri pada pengkayaan 3

Pengkayaan ke-3 (Gambar 3) pada perlakuan media mineral dengan glukosa dan penambahan $5 \mathrm{ppm}, 10$ ppm, 15 ppm pestisida serta perlakuan media mineral 
tanpa glukosa dengan penambahan $10 \mathrm{ppm}$ menunjukkan terjadinya penurunan jumlah populasi bakteri. Pada perlakuan media mineral dengan glukosa tanpa penambahan pestisida, serta perlakuan media mineral tanpa glukosa dan tanpa pemberian pestisida, penambahan 5 ppm, $15 \mathrm{ppm}$ pestisida menunjukkan terjadinya kenaikan jumlah populasi bakteri.

Hasil isolasi bakteri dari media mineral yang diberi perlakuan dengan glukosa maupun tanpa glukosa dalam masa inkubasi 5 hari pada pengkayaan tingkat 1, 2 dan 3 ditemukan 5 isolat berbeda (Tabel 1).

Tabel 1. Morfologi makroskopis isolat

\begin{tabular}{ccl}
\hline No & $\begin{array}{r}\text { Kode } \\
\text { Isolat }\end{array}$ & \multicolumn{1}{c}{ Keterangan koloni } \\
\hline 1 & BSP 1 & $\begin{array}{l}\text { Bulat kecil, putih susu, mengkilap, permu- } \\
\text { kaan rata,tepi utuh, cembung, gram negatif }\end{array}$ \\
2 & BSP 2 & $\begin{array}{l}\text { Bulat, besar, warna merah muda, cembung, } \\
\text { mengkilap, gram negatif }\end{array}$ \\
3 & BSP 3 & $\begin{array}{l}\text { Bulat kecil, transparan, tepi rata, tidak meng- } \\
\text { kilap, gram negatif }\end{array}$ \\
4 & BSP 4 & $\begin{array}{l}\text { Bulat, kecil, transparan, tepi utuh, agak cem- } \\
\text { bung, gram positif } \\
\text { Tidak beraturan,ukuran besar, putih, per- } \\
\text { mukaan rata, tepi tidak rata, gram positif }\end{array}$ \\
\hline 5
\end{tabular}

Isolat BSP 2 merupakan isolat yang mampu tumbuh dengan baik pada media mineral tanpa glukosa dengan 15 ppm pestisida. Hal ini menunjukkan isolat BSP 2 memiliki ketahanan dalam kondisi media dengan glukosa dan dengan media yang dikomposisikan dengan pestisida.

Tabel 2. Hasil uji konfirmasi isolat

\begin{tabular}{clc}
\hline No & \multicolumn{1}{c}{ Perlakuan } & $\begin{array}{c}\text { Rata- } \\
\text { Rata Nilai } \\
\text { Absorbansi }\end{array}$ \\
\hline 1 & Kontrol 15 ppm pestisida & 0,007 \\
2 & Kontrol media mineral & 0,002 \\
3 & Kontrol media mineral + 15 ppm pestisida & 0,011 \\
4 & 15 ppm Pestisida + BSP 2 & 32,071 \\
5 & Media mineral + BSP 2 & 345,695 \\
6 & Media mineral + 15 ppm pestisida + BSP 2 & 146,013 \\
\hline
\end{tabular}

Hasil uji konfirmasi isolat BSP 2 (Tabel 2) pada media mineral tanpa glukosa dengan penambahan pestisida 15 ppm selama masa inkubasi 5 hari memberikan hasil positif.

\section{PEMBAHASAN}

\section{Profil Populasi Bakteri pada Media Mineral}

Rata-rata total bakteri pada perlakuan tanpa pemberian pestisida tahap pertama pengkayaan mampu memberikan jumlah pertumbuhan yang cukup tinggi dibandingkan dengan perlakuan pada media mineral yang diberikan pestisida. Hal ini berarti bahwa pemberian pestisida 5 sampai $15 \mathrm{ppm}$ pada media mineral tanpa penambahan glukosa dapat menghambat pertumbuhan bakteri selama masa inkubasi 5 hari. Sesuai dengan pernyataan yang disampaikan oleh Sodiq (2000), bahwa penggunaan pestisida dapat menurunkan populasi bakteri tanah dan mikroorganisme tanah lainnya. Adanya residu pestisida dalam tanah dapat menurunkan populasi fauna tanah dimana pestisida seringkali mengandung senyawa aktif yang berupa senyawa kompleks sehingga bakteri sulit menguraikan senyawa tersebut menjadi senyawa yang lebih sederhana.

Sesuai dengan penelitian yang dilakukan oleh Rahmansyah dan Sulistinah (2009), bahwa media mineral yang ditambahkan senyawa pestisida mengakibatkan penurunan kemampuan tumbuh dari mikroba tanah. Adanya gangguan aktivitas enzim mengakibatkan terjadinya gangguan proses metabolisme mikroba $(\mathrm{Tu}$, 1995), walaupun demikian ada beberapa jenis mikroba asli tanah lainnya dapat bertahan dan ada kemungkinan dapat mendegradasi pestisida. Berikutnya Utami dkk. (2013), juga melaporkan bahwa penambahan pestisida propineb pada media mineral dapat menurunkan jumlah isolat yang diujikan. Lebih lanjut dikatakan pemberian pestisida propineb dapat bersifat toksik yang dapat menghambat metabolisme sehingga mikroba akan mengalami kematian.

Bakteri-bakteri yang tumbuh pada media mineral dengan penambahan $5 \mathrm{ppm}$ sampai $15 \mathrm{ppm}$ pestisida yang secara konsisten tumbuh sampai hari ke-15, memberikan peluang untuk dikembangkan sebagai isolat dalam mengatasi cemaran pestisida, walaupun perlu pembuktian lebih lanjut mengenai kemampuannya dalam menurunkan konsentrasi pestisida (Jilani, 2013). Isolat yang mampu tumbuh pada media mineral tanpa glukosa dengan penambahan pestisida konsentrasi tertinggi (15 ppm) menunjukkan ketahanan isolat terhadap cemaran pestisida sehingga isolat akan diuji kembali ketahanannya pada uji konfirmasi.

\section{Karakteristik Makroskopis Koloni Bakteri yang Ditumbuhkan pada Media Mineral}

Diperoleh 5 isolat yang paling sering ditemukan dan memiliki karakteristik yang berbeda (Gambar 4). Wahyuni dkk. (2013), menyatakan bahwa isolat yang mampu tumbuh pada medium yang dikomposisikan dengan pestisida adalah isolat yang mampu menggunakan senyawa aktif pada insektisida sebagai sumber karbon.

Empat isolat berusia 24 jam yang ditemukan memiliki bentuk koloni bulat, satu isolat berbentuk tidak beraturan. Ukuran, warna, dan morfologi isolat secara makroskopis bervariasi (Gambar 4). Isolat bakteri secara umum tidak memiliki pigmen warna, namun koloni pada isolat BSP 2 berwarna merah muda, Savitri (2006) menyatakan bahwa beberapa bakteri memiliki pigmen sehingga mewarnai koloni. karotenoid, antosianin, melanin, tripirilmethene dan phenazin merupakan pigmen yang umumnya dapat ditemukan pada bakteri.

Pertumbuhan bakteri BSP 2 dapat dibuktikan dari nilai 


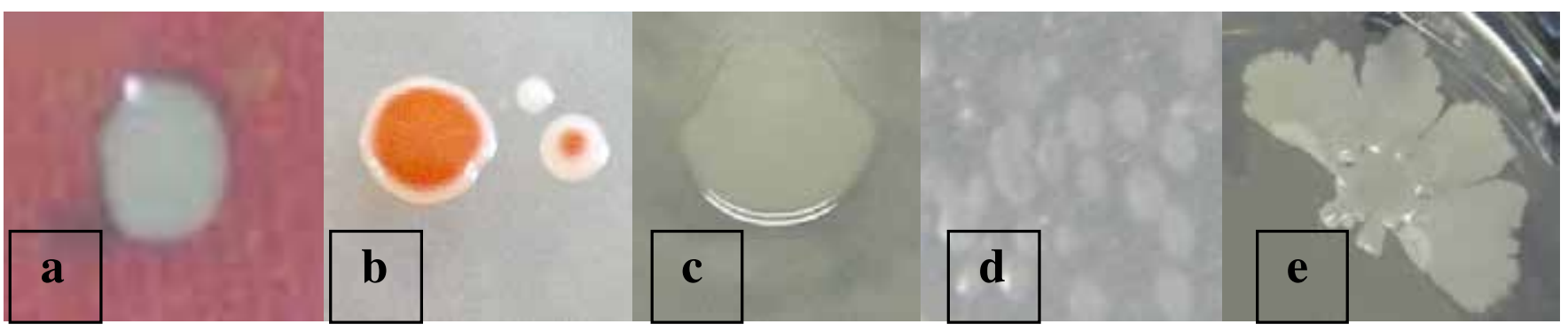

Gambar 4. Morfologi makroskopis 5 isolat

(a) koloni isolat BSP 1; (b) koloni isolat BSP 2; (c) koloni isolat BSP 3; (d) koloni isolat BSP 4; (e) koloni isolat BSP 5

absorbansi sebesar 32,071 pada media dengan penambahan $15 \mathrm{ppm}$ pestisida (Tabel 3). Beberapa penelitian telah menunjukkan bahwa beberapa genus bakteri yang diisolasi dari tanah dan perairan sungai mampu mendegradasi senyawa pestisida dan menggunakannyasebagai sumber karbon (Sulistinah dkk., 2011). Singh and Walker (2006), menyatakan kelompok bakteri fungsional yang diberikan perlakuan inokulan pestisida akan hidup lebih tahan karena memanfaatkan residu pestisida yang menjadi bagian dari sistem metabolismenya.

Kemampuan isolat BSP 2 yang dapat bertahan pada pestisida yang diujikan memberikan harapan besar isolat tersebut dapat dikembangkan sebagai agen bioremediasi khususnya dalam mendegradasi pestisida, walaupun dalam penelitian ini belum dibuktikan kemampuannya dalam menurunkan pestisida. Menurut Singhand Walker (2006), bakteri yang dapat bertahan pada perlakuan pestisida terjadi karena bakteri tersebut merupakan kelompok bakteri yang tidak terganggu oleh penambahan pestisida. Dengan memperhatikan keberadaan populasimikroba yang hidup di lingkungan tanah yang tercemar pestisida maka dapat digunakan untuk mengevaluasi suatu pengaruh cemaran pestisida.

Proses degradasi difasilitasi oleh adanya enzim fungsional yang dimiliki bakteri. Pestisida sebagai komponen asing di lingkungan tanah menimbulkan instabilitas terhadap aktivitas enzim. Enzim hidrolisa yang dihasilkan mikroba tanah dapat memutus susunan kimia pestisida. Proses oksidasi enzim di tanah pada tingkat intraseluler dilakukan oleh sel-sel bakteri yang akhirnya menyebabkan naiknya tingkat kelarutan residu tersebut menjadi unsur organik yang bisa diserap tumbuhan (Bollag and Liu, 1990). Pada uji ini perlu digunakan beberapa isolat pembanding dan dilakukan variasi kondisi lingkungan tumbuh bakteri yang sesuai agar memperoleh data yang lebih baik lagi (Flowerenti, 2001).

Isolat BSP 2 yang diperkirakan sebagai bakeri yang toleran terhadap pestisida selanjutnya diidentifikasi hingga tingkat genus atau spesies berdasarkan uji pewarnaan gram dan uji biokimia dengan menggunakan $\mathrm{BD}$ BBL Crystal E/NF ID Kit8. Isolat BSP 2 diidentifikasi sebagai bakteri Serratia marcescens. Bakteri $S$. marcescens memiliki bentuk sel batang, disebut juga Bacillus prodigiosus atau Bacterium prodigiosum yang dapat menghasilkan pigmen prodigiosin (Utami dkk. 2013).
Karakteristik reaksi biokimia S.marcescens berdasarkan pengujian terhadap 30 senyawa biokimia menggunakan Kit ID BBL Crystal E/NF menunjukkan 20 pengujian bereaksi positif. Reaksi negatif terjadi padaRhamnose, p-nitrophenyl phosphate, $p$-nitrophenyl xyloside, p-nitrophenyl phosphorylcholine, p-nitrophenyl B-glucuronide, $\gamma$-L-glutamy p-nitroanillide, p-nitro-D-L-phenylalanine, Urea, Glycine, dan Malonate.

Dalam uji indol dan oksidase isolat juga menunjukkan reaksi negatif. $S$. marcescens merupakan bakteri gram negatif dan bersifat patogen. Bakteri gram negatif memiliki dinding sel yang terdiri atas tiga lapisan polimer yang terletak di luar lapisan peptidoglikan yaitu lipoprotein, membran luar lipopolisakarida, dan fosfolipid. Sesuai dengan hasil penelitian Naphade (2012), bakteri Gram negatif mampu bertahan dalam kondisi stress akibat tingginya konsentrasi pestisida. Adanya DNA plasmid pada bakteri Gram negatif mengakibatkan bakteri mampu mentoleransi efek racun akibat penggunaan bahan kimia pestisida. Bakteri yang teridentifikasi merupakan bakteri indigenous yang bersifat patogen sehingga aplikasi bakteri sebagai agen biodegradasi mungkin dapat menimbulkan masalah. Hal ini dapat diatasi dengan memodifikasi kemampuan bakteri dengan menginsert gen pengkode produksi enzim degradasi pada spesies bakteri lain.

\section{SIMPULAN}

Perlakuan media mineral dengan penambahan pestisida berbahan aktif Klorantraniliprol (o, 5, 10, 15 ppm) mampu memberikan pengaruh yang berbeda nyata $(\mathrm{P}<0,05)$ pada pengkayaan 1,2 dan 3 , serta terdapat 5 isolat bakteri yang diisolasi dari tanah pertanian Baturiti Tabanan yaitu BSP 1, BSP 2, BSP 3 yang merupakan bakteri gram negatif, BSP 4 dan BSP 5 adalah bakteri gram positif. Bakteri yang toleran terhadap pestisida dengan bahan aktif Klorantraniliprol adalah BSP 2 dan teridentifikasi sebagai bakteri Serratia marcescens.

\section{UCAPAN TERIMAKASIH}

Bapak Drs. Yan Ramona, M.App.Sc, Ph.D., Ibu Dr. Dra. Ni Putu Adriani Astiti, M.Si., Bapak Prof. Dr. Ir. I Putu Gede Ardhana, M.Agr.Sc, SH., saran-saran, masukan dan kritiknya. 


\section{KEPUSTAKAAN}

Bollag, J.M., S.Y. Liu. 1990. Biological transformationprocesses of pesticide. In: Cheng HH (Ed), Pesticidesin the Environment: Processes, Impacts, and Modeling. Soil Science Society of America, Madison,Wl, USA, pp. 169-211.

Flowerenti, H.T. 2001. Analisis residu Metidation Dengan Metode KCKT untuk Menentukan Tingkat Bioremediasi Pestisida Organofosfat Metidation oleh Mikroba Indigenous.Institut Pertanian Bogor. Bogor.

Jilani, S. 2013. Comparative Assessment of Growth and Biodegradation Potential of Soil Isolate in The Presence of Pesticides. Saudi Journal of Biological Sciences. Vol 20: 257-264.

Maruli, A., D. N. Santi, E. Naria. 2012. Analisa Kadar Residu Insektisida Golongan Organofosfat Pada Kubis (Brassica oleracea) Setelah Pencucian dan Pemasakan diDesa Dolat Rakyat Kabupaten Karo Tahun 2012. (online jurnal).http://jurnal.usu.ac.id/ index.php/lkk/article/view/1635/937. Diakses tanggal 9 Oktober 2015.

Naphade, S.R., A. Durve, M. Bhot, J. Varghese, N. Chandra. 2012. Isolation, Characterization and Identification of Pesticide Tolerating Bacteria From Garden Soil. European J. of Experimental Biology. Vol 2(5): 1943-1951.

Patty, J.A. 2012. Peran Tanaman Aromatik Dalam Menekan Perkembangan Hama Spodoptera litura Pada Tanaman Kubis. J. Agrologia. Vol 1(2): 126-133.
Rahmansyah, M., N. Sulistinah. 2009. Performa Bakteri Pada Tanah Tercemar Pestisida. Berita Biologi. Vol 9(5): 658-664.

Savitri, S.D.N. 2006. Isolasi dan Karakterisasi Bakteri Halotoleran pada Ikan Kembung (Rastrelliger sp.) Institut Pertanian Bogor. (Skipsi).

Singh, B., A. Walker. 2006. Microbial Degradation of Organophosphorus compounds. FEMS Micro. Rev. 30. 428-471.

Sodiq, M. 2000. Pengaruh Pestisida Terhadap Kehidupan Organisme Tanah. J. Mapeta 2(5): 20-22.

Soeriadireja, P., I.G. Suka, I.N. Suarsana, A.A. Murniasih, Aliffiati, I.K. Kaler. 2014. Database Masyarakat Hukum Adat Ekoregion Bali Nusa Tenggara. Kementerian Lingkungan Hidup RI dan PS Antropologi FSB Universitas Udayana.

Sulistinah, N., S. Antonius, M. Rahmansyah. 2011. Pengaruh Residu Pestisida Terhadap Pola Populasi Bakteri dan Fungi Tanah Di Rumah Kaca. J. Tek. Ling. 12(1): 43-53.

Tu, C.M. 1995. Effect Of Five Insecticides On Microbial And Enzymatic Activities In Sandy Soil. J. of Enviro. Sci. and Health 30(3): 289-306.

Utami, D.S., N. Priyani, E. Munir. 2013. Isolasi Dan Uji Potensi Bakteri Tanah Pertanian Berastagi Sumatera Utara Dalam Mendegradasi Fungisida Antracol Berbahan Aktif Propineb. J. Saintia Biologi 1(2): 1-7.

Wahyuni, S., A.N. Ardiwinata, I.M. Sudiana. 2013. Isolasi Bakteri Pendegradasi Senyawa Persisten Organic Pollutants Asal Tanah Inceptisol Karawang. Seminar Nasional X Pendidikan Biologi FKIP UNS. Surakarta. 